DOI: $10.15193 /$ zntj/2019/118/273

\author{
BARBARA CHILCZUK, MONIKA STASZOWSKA-KARKUT, \\ MALGORZATA MATERSKA, ZENIA MICHALOJĆ
}

\title{
ZMIANY ZAWARTOŚCI WITAMINY C W OWOCACH CZTERECH ODMIAN PAPRYKI - CHLODZONYCH, MROŻONYCH I LIOFILIZOWANYCH W ZALEŻNOŚCI OD OKRESU PRZECHOWYWANIA
}

\begin{abstract}
Streszczenie
Witamina C należy do grupy egzogennych składników odżywczych, które muszą być dostarczane w codziennej diecie. Jest to związek o działaniu wielokierunkowym. Ze względu na wysoką aktywność chemiczną witamina $\mathrm{C}$ jest związkiem nietrwałym. Ulega szybkiej degradacji w tkankach roślinnych pod wpływem zewnętrznych czynników stresowych, do których należą m.in. zabiegi kulinarne. $Z$ kolei jej powolny rozkład jest procesem naturalnym zachodzącym podczas przechowywania owoców i warzyw. Do warzyw zasobnych w witaminę C należy papryka, zarówno słodka, jak i ostra. Przechowywanie owoców po zbiorze, jak również sposób konserwacji przed długoterminowym przechowywaniem wpływają na zmiany zawartości tego składnika.

W pracy określono zawartość oraz trwałość witaminy C (sumy kwasu L-askorbinowego i dehydroskorbinowego) w owocach czterech odmian papryki czerwonej. Analizowano dwie odmiany słodkie ('Aifos', 'Barbórka') oraz dwie ostre ('Cyklon', 'Cayenne'). Owoce przechowywano przez dwa tygodnie w warunkach chłodniczych jako owoce świeże, a także długoterminowo - w postaci mrożonej i liofilizowanej. Zawartość witaminy $\mathrm{C}$ oznaczono metodą spektrofluorymetryczną w reakcji z $o$-fenylenodiaminą (OPDA). Największe starty omawianego związku w owocach papryki przechowywanej w warunkach chłodniczych odnotowano w pierwszym tygodniu ich przechowywania. Wśród czterech badanych odmian największą zawartość witaminy C wykazano w ostrej papryce 'Cayenne' (470,9 mg/100 g św.m). Na podstawie uzyskanych wyników stwierdzono, że stabilność witaminy $\mathrm{C}$ podczas przechowywania i przetwarzania owoców papryki była zmienna wśród badanych odmian. Mrożenie było najkorzystniejszym sposobem utrwalania papryki, zarówno pod względem jakościowym, jak i ekonomicznym.
\end{abstract}

Słowa kluczowe: papryka czerwona, witamina C, chłodzenie, mrożenie, liofilizacja

Mgr B. Chilczuk, mgr M. Staszowska-Karkut, dr hab. M. Materska, Katedra Chemii, Wydz. Nauk o Żywności i Biotechnologii, Uniwersytet Przyrodniczy w Lublinie, ul. Akademicka 15, 20-950 Lublin, prof. dr hab. Z. Michałojć, Katedra Uprawy i Żywienia Roślin, Wydz. Ogrodnictwa i Architektury Krajobrazu, Uniwersytet Przyrodniczy w Lublinie, ul. Leszczyńskiego 58, 20-068 Lublin.

Kontakt: barbara.chilczuk@up.lublin.pl 


\section{Wprowadzenie}

Kwas L-askorbinowy jest $\gamma$-laktonem kwasu 2,3-dehydro-L-gulonowego, zwanego również L-treo-hekso-2-enonowym. Najbardziej charakterystycznym fragmentem jego cząsteczki jest ugrupowanie endiolowe, które odpowiada za właściwości redukujące oraz charakter kwasowy. Utleniona forma kwasu L-askorbinowego (kwas L-dehydroaskorbinowy) ma taką samą aktywność jak postać zredukowana. Witamina $\mathrm{C}$ jest stosunkowo trwała w stanie suchym, natomiast w roztworach wodnych bardzo łatwo ulega rozkładowi, a szybkość jej degradacji zależy od pH roztworu. Największą stabilność wykazuje w środowisku o pH $4 \div 6$ [11]. Witaminę C uważa się za najważniejszy przeciwutleniacz rozpuszczalny w wodzie, a jej funkcje biologiczne wynikają z właściwości redukujących. Może ona zapobiegać powstawaniu stresu oksydacyjnego poprzez zdolność wygaszania rodników, np. rodnika hydroksylowego i przemianę ich prekursorów, np. nadtlenku wodoru i tlenu singletowego. Organizm człowieka nie jest zdolny do syntezy witaminy $C$, ponieważ nie wytwarza oksydazy L-gulono- $\gamma$ laktonowej, enzymu koniecznego do powstawania kwasu askorbinowego. Najczęstszą przyczyną niedoboru witaminy $\mathrm{C}$ jest źle dobrana dieta. Jej niedobór prowadzi do zaburzenia homeostazy organizmu, a tym samym zwiększa ryzyko infekcji [2]. Na podstawie dostępnych badań biochemicznych, klinicznych i epidemiologicznych określono zalecane dzienne spożycie (RDA) kwasu askorbinowego w ilości $100 \div 120 \mathrm{mg} / \mathrm{dzień}$. Ilość ta ma zapewnić nasycenie komórek i zmniejszyć ryzyko chorób serca, udaru mózgu i wystąpienia nowotworów [12].

Świeże owoce i warzywa stanowią bogate źródło witaminy C. Wśród nich papryka czerwona jest jednym z bogatszych jej źródeł [4]. Zawartość witaminy $\mathrm{C}$ zależy od odmiany, sposobu uprawy, warunków pogodowych oraz od dojrzałości owoców papryki. Jej poziom w dojrzałych owocach słodkich odmian waha się w granicach $62 \div$ $150 \mathrm{mg} / 100 \mathrm{~g}$ św.m. [3, 13]. Znane są jednak odmiany, w których zawartość tej witaminy dochodzi nawet do $350 \mathrm{mg} / 100 \mathrm{~g}$ św.m. [13]. Dodatkowo forma, w jakiej występuje witamina $\mathrm{C}$ w owocach papryki, jest niezwykle odporna na działanie czynników utleniających $[13,14]$.

Kwas askorbinowy jest nietrwały, dlatego zarówno procesy przetwórcze, jak i składowanie warzyw oraz owoców wpływają niekorzystnie na poziom tego związku w produktach. Długość czasu przechowywania a także wzrastająca temperatura powodują rozpad witaminy $\mathrm{C}[8,9]$. Jednym z najczęstszych sposobów (przemysłowych i domowych) przechowywania warzyw i owoców jest mrożenie. Stała i dostatecznie niska temperatura mrożenia może zmniejszyć degradację witaminy $\mathrm{C}$, co wykazali Gonçalves i wsp. [7].

Istnieje szereg metod oznaczania witaminy $\mathrm{C}$, począwszy od analizy objętościowej, poprzez metody spektrofotometryczne aż do analizy metodą HPLC. Analiza objętościowa jest jedną z najstarszych i najprostszych metod, ale ma wiele ograniczeń. 
Podstawowe z nich to niska czułość oraz konieczność stosowania roztworów bezbarwnych. Analiza HPLC jest obecnie najczęściej stosowaną techniką analityczną, ale wymagania aparaturowe oraz szybka degradacja kolumn przy stosowanych układach redoks czyni ją bardzo kosztowną. W przedstawionej pracy do oznaczenia zawartości witaminy $\mathrm{C}$ w owocach papryki zastosowano metodę spektrofluorymetryczną. Polega ona na utlenieniu kwasu askorbinowego do dehydroaskorbinowego i jego reakcji z $o$-fenylenodiaminą, w wyniku czego powstaje fluoryzujący kompleks [16].

Celem pracy było określenie wpływu schładzania, mrożenia i liofilizacji na zawartość witaminy $\mathrm{C}$ w owocach papryki czerwonej oraz ocena trwałości tego związku podczas zamrażalniczego przechowywania mrożonek i liofilizatów.

\section{Material i metody badań}

Materiał do badań stanowiły owoce dwóch odmian papryki słodkiej: 'Aifos' i 'Barbórka' oraz dwie odmiany papryki ostrej: 'Cayenne' i 'Cyklon'. Owoce pochodziły z uprawy szklarniowej prowadzonej zgodnie z zaleceniami uprawy papryki pod osłonami w szklarni Katedry Uprawy i Nawożenia Roślin Ogrodniczych Uniwersytetu Przyrodniczego w Lublinie w latach 2014 - 2015. Owoce do badań zebrano w fazie dojrzałości zbiorczej, w pełni wybarwione na czerwono i podzielono je na trzy części. Pierwszą część zbiorów przechowywano w warunkach chłodniczych (w temp. $6{ }^{\circ} \mathrm{C}$ ). Pozostałe dwie części przeznaczone do mrożenia i liofilizacji myto, osuszano oraz krojono w drobną kostkę, a następnie zamrażano w temp. $-25^{\circ} \mathrm{C}$. Część mrożonek poddawano procesowi liofilizacji, którą prowadzono w aparacie Free Zone 12 (Labconco, USA). Suszenie sublimacyjne rozpoczynano w temp. $-50^{\circ} \mathrm{C}$ przy ciśnieniu 0,04 mbar i prowadzono przez $72 \mathrm{~h}$. Zarówno próbki mrożone, jak i liofilizowane przechowywano w szczelnie zamkniętych pojemnikach w temp. $-25^{\circ} \mathrm{C}$ do czasu analiz.

Suchą masę oznaczano metodą suszarkową początkowo w temp. $60^{\circ} \mathrm{C}$ w celu zapobieżenia krystalizacji cukrów na powierzchni próbki, a następnie w temp. $105^{\circ} \mathrm{C}$ do uzyskania stałej masy.

Oznaczanie witaminy $\mathrm{C}$ prowadzono metodą spektrofluorymetryczną zgodnie z Wu i wsp. [16], z modyfikacjami koniecznymi do oznaczeń próbek papryki. W doświadczeniu stosowano 3-procentowy kwas metafosforowy, $7 \mathrm{M} \mathrm{HCl}, 0,1 \mathrm{M} \mathrm{Na}_{2} \mathrm{~S}_{2} \mathrm{O}_{3}$, $0,005 \mathrm{M} \mathrm{H}_{2} \mathrm{SO}_{4}$. W celu przygotowania roztworu utleniającego rozpuszczano $1,3 \mathrm{~g} \mathrm{I}_{2}$ w $10 \mathrm{ml}$ 40-procentowego KI, następnie dodawano $0,1 \mathrm{ml} 7 \mathrm{M} \mathrm{HCl}$ i uzupełniano wodą destylowaną do objętości $100 \mathrm{ml}$. Odczynnik do derywatyzacji składał się z $10 \mathrm{mg}$

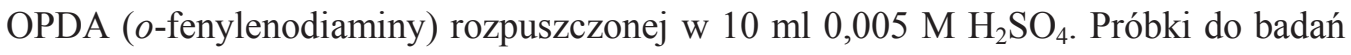
przygotowywano w następujący sposób: z 5 g surowca świeżego i mrożonego oraz $0,5 \mathrm{~g}$ liofilizatu przygotowywano ekstrakty. W tym celu naważki homogenizowano w 3-procentowym roztworze kwasu metafosforowego za pomocą homogenizatora DIAX 900 (Heidolph Instruments, Niemcy). Otrzymane ekstrakty przesączano przez 
lejek Büchnera pod zmniejszonym ciśnieniem. Końcowa objętość ekstraktu wynosiła $50 \mathrm{ml}$. Reakcje przeprowadzano w kolbach miarowych o pojemności $100 \mathrm{ml}$, do których dodawano kolejno $2 \mathrm{ml}$ badanego ekstraktu rozcieńczonego w stosunku $1: 5$ (ekstrakt : kwas metafosforowy), 0,3 $\mathrm{ml} 0,005 \mathrm{M}$ roztworu jodu w jodku potasu i wytrząsano przez $1 \mathrm{~min}$, następnie dodawano $0,3 \mathrm{ml} 0,01 \mathrm{M} \mathrm{Na}_{2} \mathrm{~S}_{2} \mathrm{O}_{3}$. Doprowadzano $\mathrm{pH}$ próbek do ok. 6,0, dodając $0,3 \mathrm{ml} 2 \mathrm{M} \mathrm{NaOH}$ i przeprowadzano derywatyzację przez dodanie po $0,3 \mathrm{ml}$ roztworu OPDA. Roztwory wytrząsano przez $30 \mathrm{~min}$. Pomiary wykonywano w spektrofluorymetrze Varian Cary Eclipse (Agilent, USA) przy długości fali wzbudzenia $\lambda=365 \mathrm{~nm}$ i długości fali emisji $\lambda=425 \mathrm{~nm}$.

Walidację metody spektrofluorymetrycznej do ilościowego oznaczania witaminy C przeprowadzano z użyciem wzorca kwasu L-askobinowego. W tym celu przygotowano roztwór startowy wzorca o stężeniu $0,1 \mathrm{mg} / \mathrm{ml} \mathrm{w}$ kwasie metafosforowym. $\mathrm{Z}$ roztworu startowego przygotowano serię rozcieńczeń w zakresie stężeń $0,004 \div$ $0,1 \mathrm{mg} / \mathrm{ml}$. Następnie wykonano oznaczenia zgodnie $\mathrm{z}$ opisaną wyżej procedurą. $\mathrm{Na}$ podstawie wielkości fluorescencji (y) badanych stężeń wzorca (x) wykreślono krzywą kalibracyjną $\mathrm{y}=\mathrm{f}(\mathrm{x})$. Zakres stężeń wzorca, przy którym krzywa miała charakter liniowy określono na podstawie wartości $\mathrm{R}^{2}$, która była co najmniej rzędu 0,999. Limit detekcji (LOD) oraz granicę oznaczalności (LOQ) obliczano na podstawie parametrów krzywej kalibracyjnej otrzymanej w warunkach prowadzonych analiz. Wartości zakresu liniowości oraz równanie krzywej przedstawiono w tab. 1.

Tabela 1. Parametry walidacyjne metody spektrofluorymetrycznej do oznaczania witaminy C

Table 1. Validation parameters of spectrofluorimetric method for determining content of vitamin C

\begin{tabular}{||c|c|c|c|c||}
\hline $\begin{array}{c}\text { Zakres stężeń } \\
\text { Concentration range } \\
{[\mathrm{mg} / \mathrm{ml}]}\end{array}$ & $\begin{array}{c}\text { Równanie regresji liniowej } \\
\text { Linear regression equation }\end{array}$ & $\mathrm{R}^{2}$ & $\begin{array}{c}\mathrm{LOD} \\
{[\mathrm{mg} / \mathrm{ml}]}\end{array}$ & $\begin{array}{c}\text { LOQ } \\
{[\mathrm{mg} / \mathrm{ml}]}\end{array}$ \\
\hline $0,1-0,01$ & $\mathrm{y}=1587,2 \mathrm{x}-4,9636$ & 0,9998 & 0,004 & 0,013 \\
\hline
\end{tabular}

Zawartość witaminy $\mathrm{C}$ w analizowanych próbkach przeliczano na 100 g świeżej masy (św.m.) na podstawie równania:

$$
Z=\frac{A \cdot B \cdot C \cdot 100}{D \cdot E}
$$

gdzie:

$Z$ - zawartość witaminy C [mg/100 g św.m.],

$A$ - odczyt z równania krzywej wzorcowej [mg/100 ml],

$B$ - objętość ekstraktu z papryki [ml],

$C$-objętość mieszaniny reakcyjnej [ml],

$D$ - naważka papryki [g], 
$E$ - objętość ekstraktu pobrana do analizy [ml].

Badania prowadzono przez 27 tygodni od zbioru. W świeżych owocach pomiary wykonywano: w dniu zbioru (T0), po upływie 1 tygodnia (T1) oraz 2 tygodni (T2) przechowywania całych owoców w warunkach chłodniczych w temp. $6{ }^{\circ} \mathrm{C}$. W owocach mrożonych fluorescencję mierzono po upływie 1, 2, 7, 17 oraz 27 tygodni od zbioru. Analizę owoców liofilizowanych przeprowadzano po 2 tygodniach, a następnie tak jak w przypadku próbek mrożonych.

Wyniki przedstawione jako wartości średnie z trzech powtórzeń poddano analizie statystycznej. Istotność różnic między wartościami średnimi określono za pomocą testu Tukeya przy $\mathrm{p}<0,05$. Analizę wykonano w programie Statgraphic Centurion XVI.

\section{Wyniki i dyskusja}

Analizowane odmiany papryki różniły się cechami morfologicznymi, ostrością oraz zawartością suchej masy. Odmiany słodkie miały większe owoce i zawierały więcej wody. Odmiany ostre miały mniejsze owoce, które cechowały się większą zawartością suchej masy. Charakterystykę badanych odmian papryki przedstawiono w tab. 2.

Tabela 2. Charakterystyka owoców badanych odmian papryki

Table 2. Traits of the fruits of the analysed pepper cultivars

\begin{tabular}{||c|c|c|c|c||}
\hline \hline $\begin{array}{c}\text { Odmiana papryki } \\
\text { Pepper cultivar }\end{array}$ & $\begin{array}{c}\text { Sucha masa } \\
\text { Dry matter [\%] }\end{array}$ & $\begin{array}{c}\text { Długość owocu } \\
\text { Fruit length [cm] }\end{array}$ & $\begin{array}{c}\text { Średnica owocu } \\
\text { Fruit diameter [cm] }\end{array}$ & $\begin{array}{c}\text { Masa owocu } \\
\text { Fruit weight [g] }\end{array}$ \\
\hline $\begin{array}{c}\text { Słodka / Sweet: } \\
\text { 'Aifos' }\end{array}$ & $7,2 \pm 0,58$ & $8,1 \pm 0,67$ & $8,4 \pm 0,56$ & $162,3 \pm 1,21$ \\
'Barbórka' & $8,7 \pm 0,06$ & $9,6 \pm 0,52$ & $7,1 \pm 0,58$ & $112,6 \pm 1,15$ \\
Ostra / Hot: & & & & \\
'Cyklon' & $12,5 \pm 0,11$ & $9,4 \pm 0,55$ & $3,4 \pm 0,41$ & $14,7 \pm 0,67$ \\
'Cayenne' & $28,8 \pm 0,91$ & $10,64 \pm 0,98$ & $1,0 \pm 0,19$ & $4,9 \pm 0,48$ \\
\hline
\end{tabular}

Po porównaniu zawartości witaminy $\mathrm{C} \mathrm{w}$ badanych odmianach papryki stwierdzono, że najwięcej było jej w odmianie ostrej 'Cayenne'. W pozostałych analizowanych odmianach zawartość omawianego związku była na zbliżonym poziomie (rys. 1). Z badań własnych wynika, że zawartość kwasu askorbinowego zależała od rodzaju papryki, co jest potwierdzeniem wcześniejszych badań Surmy-Zadory i wsp. [15]. Golcz i Kozik [6] wykazali, że zawartość witaminy C w słodkiej odmianie papryki czerwonej wahała się w zakresie $244 \div 316 \mathrm{mg} / 100 \mathrm{~g}$ św. m., a w odmianie ostrej $358 \div 457 \mathrm{mg} / 100 \mathrm{~g}$ św.m.

Przechowywanie całych owoców papryki w warunkach chłodniczych skutkowało zmniejszeniem zawartości witaminy $\mathrm{C}$, a dynamika zmian była największa w pierwszym tygodniu od zbioru i zależała od wyjściowej zawartości tego związku (rys. 1). 


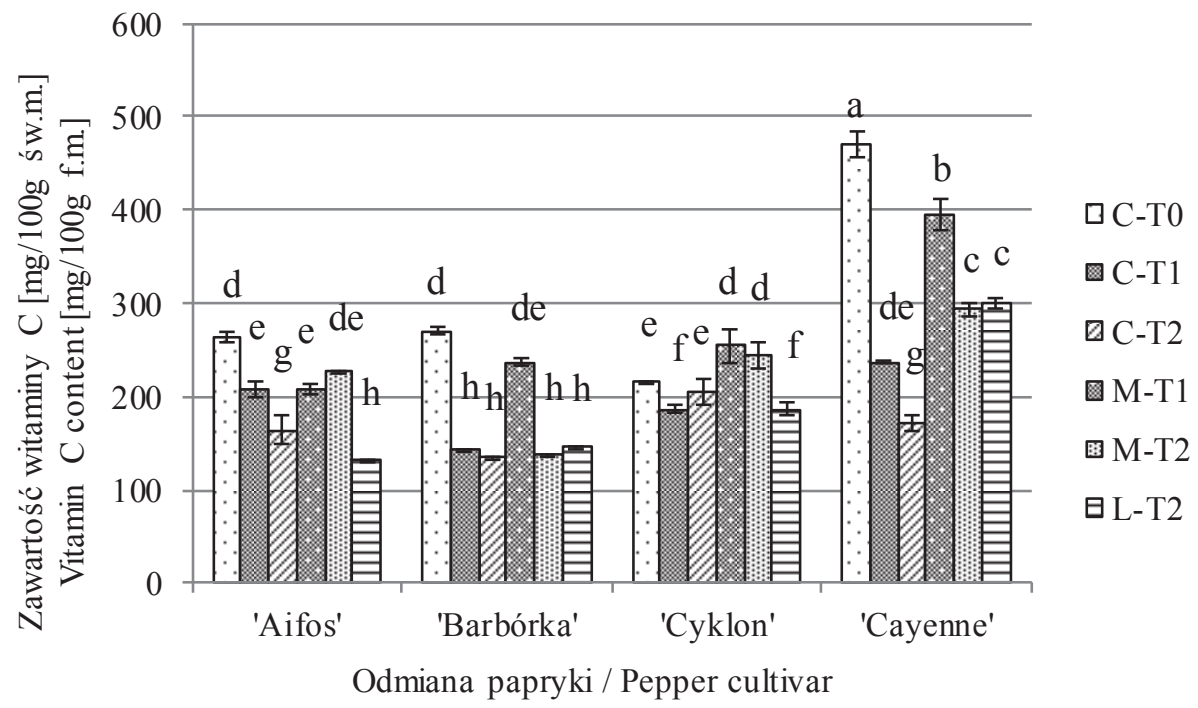

Objaśnienia / Explanatory notes:

$\mathrm{Na}$ rysunku przedstawiono wartości średnie (w postaci słupków) i odchylenia standardowe (w postaci odcinków) / Figure shows mean values (bars) and standard deviations (line segments); a, b, .. - wartości średnie oznaczone różnymi literami różną się statystycznie istotnie $(\mathrm{p}<0,05)$ / mean values denoted by different letters differ statistically significantly at $\mathrm{p}<0.05$.

Rys. 1. Zawartość witaminy $\mathrm{C}$ w czterech odmianach papryki: w dniu zbioru (T0), po jednym tygodniu (T1) i po dwóch tygodniach (T2) przechowywania chłodniczego owoców całych (C) oraz przechowywania zamrażalniczego owoców mrożonych (M) i liofilizowanych (L)

Fig. 1. Content of vitamin $\mathrm{C}$ in four varieties of red pepper on day of collection (T0), after one (T1) and two weeks (T2) of cold storage of whole fruit (C) and of freezing storage of frozen (M) and freeze-dried (L) fruits

W owocach odmiany 'Cayenne', zawierającej najwięcej witaminy C, zaobserwowano największe jej straty, które po jednym tygodniu przechowywania dochodziły do $50 \%$. W odmianie 'Cyklon', charakteryzującej się najmniejszą zawartością tego związku, odnotowano najmniejsze straty, które wynosiły ponad 14 \% (rys. 1). W drugim tygodniu przechowywania następowała dalsza degradacja witaminy $\mathrm{C}$, ale zmiany te były mniej dynamiczne. Dodatkowo w omawianym okresie przechowywania wystąpił nieznaczny wzrost zawartości witaminy $\mathrm{C}$ w owocach odmiany 'Cyklon' (rys. 1). Podobnie Andrade Cuvi i wsp. [1] w badaniach prowadzonych nad wpływem przechowywania papryki w warunkach chłodniczych na jej właściwości przeciwutleniające oraz zawartość witaminy $\mathrm{C}$ odnotowali tendencję wzrostową zawartości witaminy $\mathrm{C}$. Tłumaczyli to tym, że uszkodzone tkanki zwiększyły produkcję kwasu askorbinowego w celach ochronnych komórek pomimo niskiej temperatury. 
W owocach papryki, jak w każdej tkance roślinnej, zachodzi wiele procesów biochemicznych związanych m.in. z oddychaniem komórkowym czy też z odpowiedzią na stres temperaturowy lub związanych z apoptozą komórek. Procesy te mogą wpływać bezpośrednio lub pośrednio, zarówno na syntezę, jak i degradację witaminy $\mathrm{C}$ w komórkach. W przedstawionych badaniach przechowywano nieuszkodzone owoce papryki, zatem wzmożona synteza witaminy $\mathrm{C}$ może być wynikiem stresu temperaturowego oraz związanego z oddzieleniem owocu od rośliny. Degradacja witaminy C może zachodzić na skutek reakcji tego związku z wolnymi rodnikami uwalnianymi w komórkach pod wpływem czynników stresowych [3]. Zaobserwowany wzrost zawartości witaminy C w owocach odmiany 'Cyklon' można tłumaczyć tym, że wypadkowa syntezy i degradacji witaminy $\mathrm{C}$ była w nich dodatnia.

Analizy wpływu procesu mrożenia oraz liofilizacji na trwałość witaminy $\mathrm{C}$ można dokonać na podstawie wyników uzyskanych po dwóch tygodniach od zbioru (rys. 1). W tym przypadku w owocach wszystkich odmian odnotowano większą trwałość omawianego związku w próbkach mrożonych w porównaniu z przechowywanymi w całości w warunkach chłodniczych. Dodatkowo w przypadku odmiany 'Cyklon' stwierdzono większą zawartość omawianego związku w owocach mrożonych w porównaniu ze świeżymi $\mathrm{w}$ dniu zbioru (rys. 1). W temperaturze poniżej $0{ }^{\circ} \mathrm{C}$ wstrzymana zostaje aktywność enzymów prowadzących do degradacji witaminy $\mathrm{C}$, a skład chemiczny tkanek jest niezmienny, co może tłumaczyć uzyskane wyniki. Ponadto wzmożona synteza witaminy $\mathrm{C}$ może być odpowiedzią układu na stres temperaturowy. Podobnie stymulujący wpływ mrożenia na syntezę witaminy $\mathrm{C}$ wykazali w mrożonych malinach Ancos i wsp. [5].

Proces liofilizacji związany jest $\mathrm{z}$ usunięciem wody z tkanek, a poprzedza go uprzednie zamrożenie próbki. $Z$ tego względu na zmiany zawartości analizowanego składnika nakładają się trzy elementy: zamrażanie, liofilizacja oraz przechowywanie liofilizatów. Na podstawie wyników badań własnych stwierdzono, że liofilizacja owoców była najmniej korzystna w przypadku papryki odmiany 'Aifos', która charakteryzowała się dużą zawartością wody (tab. 2). W liofilizowanych owocach tej odmiany, $\mathrm{w}$ drugim tygodniu po zbiorze, odnotowano największy ubytek witaminy $\mathrm{C}$ w porównaniu $\mathrm{z}$ zawartością tego związku w całych owocach papryki przechowywanych chłodniczo przez dwa tygodnie (rys. 1). Z kolei w drugiej słodkiej odmianie papryki ('Barbórka'), która charakteryzowała się porównywalną zawartością wody w owocach, nie stwierdzono negatywnego wpływu procesu liofilizacji na poziom witaminy $\mathrm{C}$ $\mathrm{w}$ tkankach. W odmianie tej $\mathrm{w}$ drugim tygodniu od zbioru stwierdzono porównywalne zawartości witaminy $\mathrm{C}$, zarówno w owocach chłodzonych w całości, jak też mrożonych i liofilizowanych (rys. 1). Można zatem stwierdzić, że w zależności od odmiany trwałość witaminy $\mathrm{C} w$ procesach utrwalania papryki jest zmienna i nie zależy od zawartości wody w owocach. Martinez i wsp. [10] po przeanalizowaniu wpływu prze- 
chowywania, mrożenia i liofilizacji owoców jednej odmiany papryki słodkiej zebranej w kilku fazach dojrzałości stwierdzili, że przechowywanie owoców w pełnej dojrzałości, do 20 dni w warunkach chłodniczych, skutkowało zmniejszeniem zawartości witaminy C o ok. $15 \%$. Jednocześnie ci sami autorzy nie wykazali ujemnego wpływu procesu liofilizacji na poziom zawartości omawianego związku. Wyniki badań własnych dotyczące papryki odmiany 'Cyklon' i 'Barbórka' są zbliżone do rezultatów wymienionych autorów.
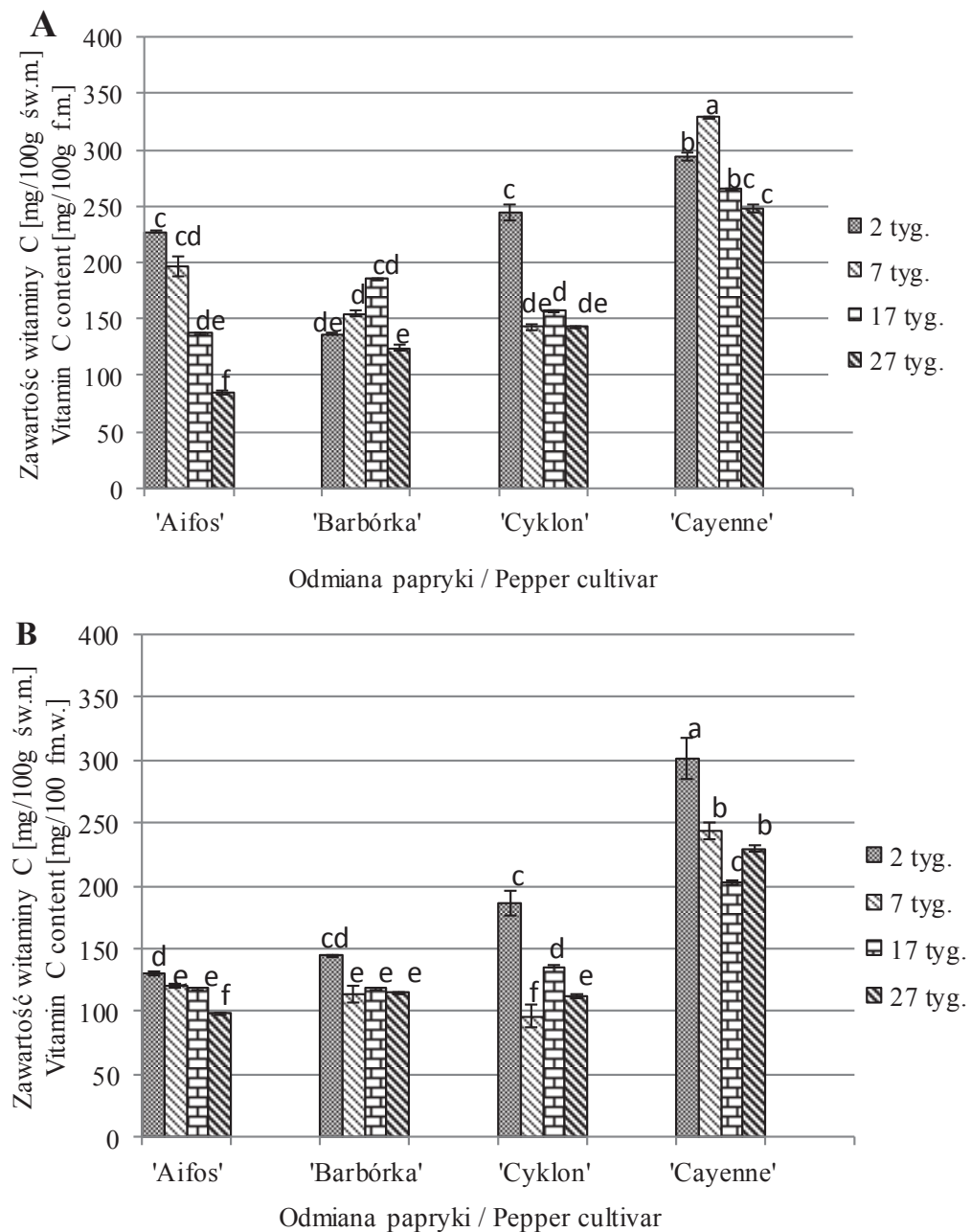

Objaśnienia jak pod rys. 1. / Explanatory notes as in Fig. 1.

Rys. 2. Zmiany zawartości witaminy $\mathrm{C}$ w owocach papryki mrożonej (A) i liofilizowanej (B) w trakcie przechowywania

Fig. 2. Changes in content of vitamin $\mathrm{C}$ in fruit of frozen (A) and freeze-dried (B) red pepper during storage 
Papryka w postaci mrożonek czy też liofilizatów może być przechowywana przez kilkadziesiąt dni, co niewątpliwie wpływa na zmiany jej składu chemicznego. Z tego względu kolejnym etapem badań było określenie trwałości witaminy $\mathrm{C} \mathrm{w}$ dłuższym okresie przechowywania, który wynosił 27 tygodni od zbioru, czyli 189 dni.

Na rys. 2. przedstawiono zmiany zawartości witaminy $\mathrm{C} w$ mrożonych (rys. 2A) oraz liofilizowanych (rys. 2B) owocach papryki począwszy od 2 do 27 tygodni od zbioru. Na podstawie uzyskanych wyników stwierdzono, że witamina $\mathrm{C}$ występująca w papryce charakteryzowała się wysoką trwałością w badanym okresie przechowywania. W zależności jednak od odmiany zaobserwowano różną dynamikę zmian jej zawartości w owocach mrożonych oraz liofilizowanych. Odmiana 'Aifos' charakteryzowała się większą stabilnością tego związku w owocach liofilizowanych i tym samym większą jego zawartością po 27 tygodniach przechowywania niż w przypadku mrożonek (rys. 2). Z kolei w pozostałych badanych odmianach papryki większą trwałość witaminy $\mathrm{C}$ po 27 tygodniach przechowywania odnotowano w przypadku mrożonek. W papryce odmiany 'Cayenne' największą zawartość witaminy C oznaczono w końcowym terminie badań niezależnie od sposobu utrwalenia próbek.

Podsumowując, można stwierdzić, że badane odmiany papryki charakteryzowały się zmienną trwałością witaminy $\mathrm{C}$ w analizowanym okresie przechowywania. Ze względu na bogaty skład chemiczny owoców papryki nie można jednoznacznie powiązać trwałości badanego związku z jednym elementem, takim jak zawartość wody, ostrość, barwa itp. W przeprowadzonych badaniach wykazano, że jedynie w przypadku jednej odmiany korzystniejszą formą utrwalania owoców, pod względem trwałości witaminy $\mathrm{C}$ podczas przechowywania, była liofilizacja. Zatem uwzględniając wysoki koszt procesu liofilizacji uzasadnione jest stwierdzenie, że mrożenie papryki jest korzystniejsze zarówno pod względem jakościowym jak i ekonomicznym.

\section{Wnioski}

1. Zawartość witaminy $\mathrm{C}$ w badanych odmianach papryki była zróżnicowana, a najwięcej badanego związku występowało w owocach odmiany 'Cayenne'.

2. Największy ubytek witaminy $\mathrm{C}$ stwierdzono w pierwszym tygodniu od zbioru we wszystkich badanych odmianach papryki.

3. Długoterminowe przechowywanie mrożonych owoców papryki jest korzystniejsze pod względem zachowania zawartości witaminy $\mathrm{C}$ niż przechowywanie w postaci zliofilizowanej. 


\section{Literatura}

[1] Andrade Cuvi M.J., Vicente A.R., Concellón A., Chaves A.R.: Changes in red pepper antioxidants as affected by UV-C treatments and storage at chilling temperatures. LWT - Food Sci. Technol., 2011, 44 (7), 1666-1671.

[2] Daud Z.A.M., Ismail A., Sarmadi B.: Ascorbic Acid: Physiology and Health Effects. In: Encyclopedia of Food and Health. Eds. B. Caballero, P. Finglas, F. Toldra. Academic Press, Fargo, North Dakota, 2016, pp. 266-274.

[3] Davey M.W., Montagu M.V., Inze D., Sanmartin M., Kanellis A., Smirnoff N., Benzie I.J.J., Strain J.J., Favell D., Fletcher J.: Review: Plant L-ascorbic acid: Chemistry, function, metabolism, bioavailability and effects of processing. J. Sci. Food Agric., 2000, 80, 825-860.

[4] Da Silveira Agostini-Costa T., da Silva Gomes I., de Melo L.A.M.P., Reifschneider F.J.B., Da Costa Ribeiro C.S.: Carotenoid and total vitamin C content of peppers from selected Brazilian cultivars. J. Food Com. Anal., 2017, 57, 73-79.

[5] De Ancos B., Gonzalez E.M., Cano M.P.: Ellagic acid, vitamin C, and total phenolic contents and radical scavenging capacity affected by freezing and frozen storage in raspberry fruit. J. Agric. Food Chem., 2000, 48, 4565-4570.

[6] Golcz A., Kozik E.: Effect of several agrotechnical factors on vitamin C content in pepper (Capsicum annuum L.) and lettuce (Lactuca sativa L.). Rocz. AR w Poznaniu, 2004, CCCLVI, pp.67-74.

[7] Gonçalves E.M., Abreu M., Brandão T.R.S., Silva C.L.M.: Degradation kinetics of colour, vitamin $\mathrm{C}$ and drip loss in frozen broccoli (Brassica oleracea L. ssp. Italica) during storage at isothermal and non-isothermal conditions. Int. J. Refr., 2011, 34, 2136-2144.

[8] Herbig A.L., Renard M.G.C.: Factors that impact the stability of vitamin C at intermediate temperatures in a food matrix. Food Chem., 2017, 220, 444-451.

[9] Klimczak I., Małecka M., Szlachta M., Gliszczyńska-Świgło A.: Effect of storage on the content of polyphenols, vitamin C and the antioxidant activity of orange juices. J. Food Comp. Anal., 2007, 20, 313-322.

[10] Martinez S., Lopez M., Gonzalez-Raurich M., Bernardo Alvarez A.: The effects of ripening stage and processing systems on vitamin $\mathrm{C}$ content in sweet peppers (Capsicum annuum L.). Int. J. Food Sci. Nutr., 2005, 56 (1), 45-51.

[11] Moszczyński P., Pyć R.: Biochemia wiatmin. Część II. Witaminy lipofilne i kwas akorbinowy. Wyd. Nauk. PWN, Łódź 1999.

[12] Naidu K.A.: Vitamin C in human health and disease is still a mystery? An overview. J. Nutr., 2003, 2, 7-16.

[13] Palevitch D., Craker L.E.: Nutritional and medicinal importance of red pepper (Capsicum spp.). J. Herbs Spices Med. Plants, 1995, 3, 55-83.

[14] Perucka I., Materska M.: Antioxidant vitamin contents of Capsicum annuum fruit extracts as affected by processing and varietal factors. Acta Sci. Pol., Technol. Aliment., 2007, 6 (4), 67-74.

[15] Surma-Zadora M., Cieślik E., Grzych-Tuleja E., Bodzioch A.: Próba znalezienia współzależności pomiędzy zawartością witaminy C a barwą papryki. Bromat. Chem. Toksykol., 2011, XLIV, 1, 1724.

[16] Wu X., Diao Y., Sun C.H., Yang J., Wang Y., Sun S.: Fluorimetric determination of ascorbic acid with o-phenylenediamine. Talanta, 2003, 1, (42), 95-99. 


\title{
CHANGES IN CONTENT OF VITAMIN C IN REFRIGERATED, FROZEN AND LYOPHILIZED FRUITS OF FOUR VARIETIES OF PEPPER DEPENDING ON STORAGE PERIOD
}

\author{
$\mathrm{S} \mathrm{u} \mathrm{m} \mathrm{m} \mathrm{a} \mathrm{r} \mathrm{y}$
}

Vitamin $\mathrm{C}$ belongs to a group of exogenous nutritional components that must be supplied in the daily diet. It is a compound showing multidirectional actions. Vitamin $\mathrm{C}$ is an unstable compound owing to its high chemical activity. It degrades rapidly in plant tissues owing to the impact of external stress factors, including, among inter alia, culinary treatments. On the other hand, its slow decomposition is a natural process that occurs during storage of fruits and vegetables. Sweet and spicy peppers are vegetables rich in vitamin C. Storing fruits after harvest and the method of preserving them prior to a long-term storage affect changes in the concentration of that ingredient.

In the research study, there were determined the content and the durability of vitamin $\mathrm{C}$ (sum of L-ascorbic acid and dehydroscorbic acid) in the fruits of four varieties of red pepper. Two sweet ('Aifos', 'Barbórka') and two spicy ('Cyklon', 'Cayenne') varieties were analysed. The fruits were stored as fresh fruit under the refrigeration conditions for two weeks and also in the long term as frozen and lyophilized fruit. The content of vitamin $\mathrm{C}$ was determined by an aspectro-fluorimetric method in a reaction with o-phenylenediamine (OPDA). The highest losses of the compound analysed were recorded in the fruit of peppers stored under the refrigeration conditions in the first week of its storage. Of the four varieties studied, in the 'Cayenne' hot variety was recorded the highest concentration of vitamin C (470.9 mg/100 g f.m.). Based on the results obtained it was found that in the pepper varieties analysed the stability of vitamin $\mathrm{C}$ varied during storage and processing of pepper fruits. Freezing was the most beneficial method to preserve peppers both in quality and economic terms.

Key words: red peppers, vitamin C, refrigeration, freezing, lyophilisation 